\title{
MILITÂNCIA VISUAL PARA ALÉM DA PASSIVIDADE: ARTISTAS, VIADAS, MULHERES E DEMAIS ALTERIDADES BOTANDO A CARA NO SOL!
}

\author{
Rodrigo Torres do Nascimento ${ }^{\mathrm{i}}$ \\ Aldo Victorio Filho \\ Pâmela Souza da Silva ${ }^{\text {iii }}$
}

\section{RESUMO}

A pesquisa da qual resulta esse artigo tem como referência duas personagens do meio artístico popular, a performer, cantora e dançarina Inês Brasil e o grupo musical Bonde das Bonecas. Ambos assumem visualidades inseparáveis do viés político que é a afirmação pública e poética de estéticas comumente rejeitadas pelos critérios hegemônicos de gosto e beleza. Embora nosso tema envolva o campo da Estética como interseção da Teoria do Gosto, Teoria da Beleza e Filosofia da Arte, e reconheçamos a potência estética dos seus trabalhos, não interessou ao debate deflagrado classificar ou discutir as qualidades ou localização das produções de Inês e do Bonde no campo da Arte. E sim os aspectos relacionados ao gosto e à beleza como instâncias de tensão política como centrais à discussão proposta.

Palavras-Chave: Gênero; Corpos; Cultura visual; Juventude; Educação.

\section{VISUAL ACTIVISM BEYOND PASSIVITY: ARTISTS, QUEER PEOPLE, DYKES, WOMEN AND OTHERNESS, ALL CHASING THE SUN!}

\begin{abstract}
The research supporting this article is about two popular art characters; the performer, singer and dancer Inês Brasil and the musical group Bonde das Bonecas. Both assume political visualities, once they publicly elect poetics and aesthetics that are currently rejected by hegemonic beauty standards and taste for the-so-called-art. Although we recognize the aesthetical power of their work and our theme envolves Aesthetics, Theory of Taste, Theory of Beauty and Art Philosophy, it did not interest us to classify or debate the quality nor place of their productions in the Arts field, but the aspects related to taste and beauty as they provoke the political tension that is central to the proposed discussion.
\end{abstract}

Key words: Gender; Bodies; Visual culture; Youth, Education. 
Percorrendo a História da Arte, que é também parte da história das imagens, percebemos que a imagem é um dispositivo de força política inconteste tanto sob o aspecto da representação, quanto no da presença pessoal e ou coletiva. As roupas e assessórios que compõem o visual pessoal transmitem mensagens importantes de identificação com semelhantes e também de controle dos corpos. Os uniformes, no que the diz respeito, mais que protegerem corpos e ambientes, em fábricas, escolas ou quartéis, funcionam também para afirmar hierarquias, territórios e poderes. O mesmo ocorre com o preparo e circulação das máscaras sociais, entendidas desde o início da civilização humana como o conjunto de elementos que evidencia os papéis sociais predeterminados à vida de cada sujeito. Ou seja, as máscaras se ligam ao gênero, como o de marido, esposa, pai, mãe, filho, etc.

A suposta defesa à adequação de vestuário e comportamento relativos a ambientes e funções oculta outros interesses e podem sustentar os mais terríveis argumentos a favor de violências diversas. A esse respeito, podemos e devemos apontar como exemplo emblemático a corriqueira fala machista que atribui à indumentária da mulher a causa de sua agressão e discriminação. Oriunda desta mesma lamentável crença ou política, toda sorte de discriminação é ativada e justificada pela audácia do outro ser o que quer ser e aparentar, ou mesmo fazer de si o que lhe agrada a despeito dos manuais de conduta e controle que se naturalizou impor. A transgressão às predeterminações sociais, e a fuga às tradições que cerceiam a liberdade individual e reprimem o desejo, arriscam preços altos, contudo, por outro lado, descortinam possibilidades de existências mais felizes.

Há portanto, o estabelecimento de uma luta a partir da afirmação de estéticas individuais que contrastam com o comum e desobedecem as normas. As visualidades pessoais emergem como forma de ação política.

A pesquisa da qual resulta esse artigo tem como referência duas personagens do meio artístico popular, a performer, cantora e dançarina Inês Brasil e o grupo musical Bonde das Bonecas. Ambos assumem visualidades inseparáveis do viés político que é a afirmação pública e poética de estéticas comumente rejeitadas pelos critérios hegemônicos de gosto e beleza. Embora nosso tema envolva o campo da Estética como interseção da Teoria do Gosto, Teoria da Beleza e Filosofia da Arte, e reconheçamos a potência estética dos seus trabalhos, não interessou ao debate deflagrado classificar ou discutir as qualidades ou localização das produções de Inês e do Bonde no campo da Arte. E sim os aspectos relacionados ao gosto e à beleza como instâncias de tensão política como centrais à discussão proposta. 


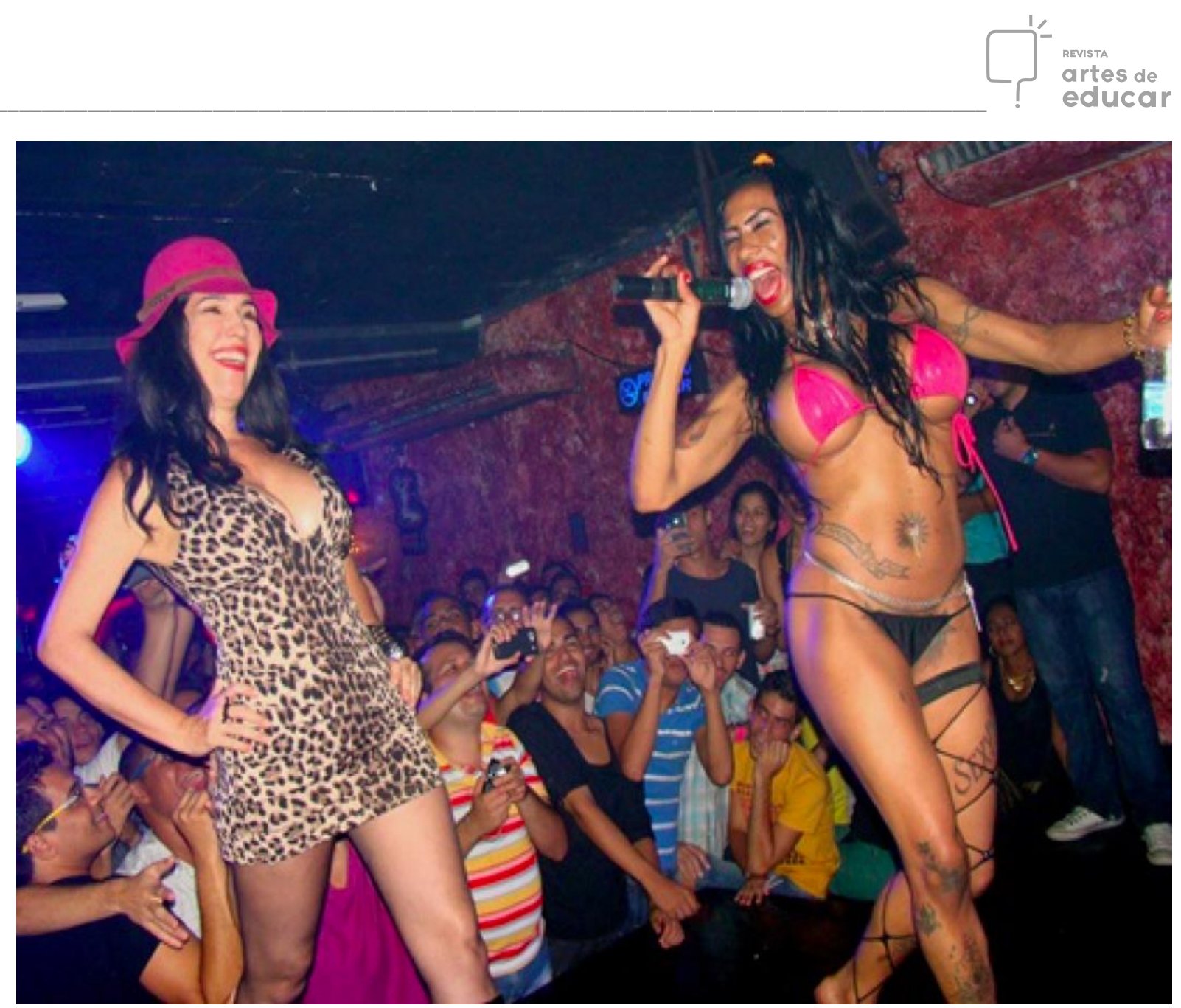

Fonte: Site oficial do Clube Metropole, (Ano desconhecido).

O público majoritário de Inês e do Bonde, como é peculiar às juventudes, projeta suas ações de luta e resistência no próprio corpo. O corpo juvenil, divertido e estetizado, se constitui, claramente desde meados do século passado, como dispositivo de luta, das imagens pessoais aos vocabulários criados e utilizados. Os jovens aos quais alude a pesquisa, em muitos sentidos periferizados e em sua maioria pobres, transgridem e escapam dos guetos da passividade e transparência que a diagramação da cidade lhes reserva. Sua transgressão começa na insistência em mudar o que lhes é imposto pela pobreza material, afinal ser vítima da pobreza por si só já caracteriza uma transgressão criminosa, ao gênero, à sexualidade e consequentemente à aparência. Nessa perspectiva, destacamos a força das estéticas pessoais na militância visual que emerge resistência política à invisibilidade imposta pelos grupos dominantes a todos que ousam não lhes ter como modelo.

Em outros termos, estes jovens descartam as máscaras sociais que lhes foram destinadas, via de regra tingidas pelo cinza da subalternidade, por meio da criação de cores e texturas de suas 
visualidades pessoais, realizando, conscientes ou não, o que Mirzoeff denomina "visual activism” (2015 p. 274).

Nessas operações é ativada a riqueza de seus desejos em suas afirmações no mundo. Entendemos que tal emergência, a presença social, o desfrute junto aos seus coletivos, pode ser apontada como energia central na relação da estética com a vida. Relação que, por sua vez, emerge como franca exigência da autoria da própria existência e dos sempre necessários abrigos identitários. Estes jovens, como a maioria dos jovens, formam coletivos, criam saberes, invertem, transviam, subvertem e corrompem o discurso que lhes quer fazer estranhos e indesejáveis e, assim, mostram que a beleza, a correção, o saber e as demais criações humanas são fundamentalmente relativas e só pautáveis por normas e manuais sob a força da violência, ou seja, da covardia.

Assim, os interlocutores da pesquisa criam continuamente ressignificações para termos originalmente agressivos, como, "bicha", "viado", "trava”, "sapatão”. A corrupção do sentido desses termos originalmente agressivos é um dos meios, por sinal de grande relevância, com os quais a juventude viada cada vez mais se afirme nas próprias maneiras de existir. Afinal, se a existência em momentos cruciais acontece no enunciado, no horizonte impalpável do signo, e é reconhecida no nome e na sua pronúncia, as denominações são, portanto, também campo de batalha. A investigação encontrou, então, indissociável das visualidades, tomadas de território através da fala, pela introdução de vocabulários que subvertem a maldição para invocar a inclusão dos atingidos pelo nome - xingamento, condenação, estigmatização - na luminosa licitude do real. Real, bem o sabemos, sempre plural e instável. O mesmo se dá com as visualidades, nestes casos como modos de experiência ao mesmo tempo pessoal e coletiva por meio da amalgama entre o suporte, o corpo e a obra, ou seja, o que é feito dele. É, assim, a consecução de imagens nas quais e por meio das quais se deseja fulgurar. Muitas vezes, por meio de materialidade rejeitada, corpos, indumentárias, etc, transformada via o manejo político da imagem em objeto de identificação, realização, orgulho, em moda, estilo e obra poética.

O conceito de visualidade utilizado nesse artigo, como nos estudos da Cultura Visual, é tomado como tessitura complexa que atinge e envolve imagem e contemplador. Deslocando este último da segurança de quem apenas vê para o risco inevitável que corre aquele que edita, complementa e finaliza o que olha. Assim como se dá na incorporação de falas, reutilização de expressões e aplicação de sotaques e vocabulários, os grupos malditos agregam imagens e modos de veiculálas. Afinal, todo corpo é imagem em trânsito, em outros termos, trata-se da trajetória alegre de suas conquistas no mundo com a potência de transfigurar maldição em epifania, por mais fugaz 


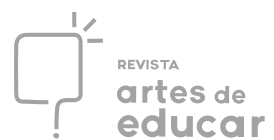

ou transitória que possa parecer e ser. "Close" ou "pinta", comportamento ostensivo de pertencimento à trama cultural que denominamos viada diante do risco constante de reações violentas repressão, é por isso mesmo duplamente positivo. Configura a liberdade individual em absoluta pertinência e o enfrentamento político que toda rebeldia veicula.

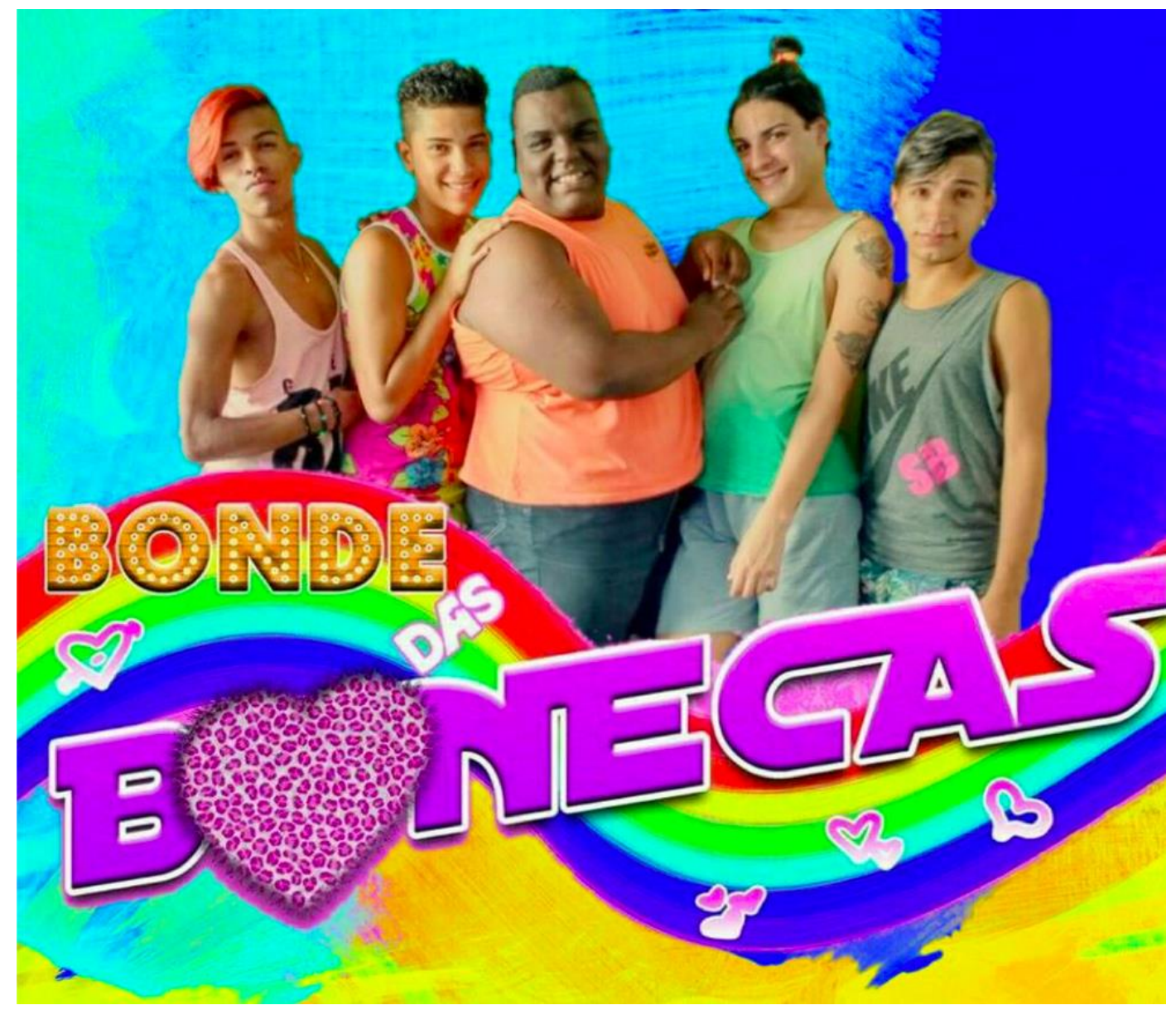

Fonte: Página oficial do Bonde das Bonecas no Facebook, (2016).

As imagens, vídeos e performances publicados por essa parcela da juventude nas redes sociais se relacionam diretamente com construções e desconstruções identitárias. Exibem a plasticidade do que seria o "identitário", visto que no mesmo fluxo, abrigos identitários são construídos, utilizados e abandonados. Tornam-se lugares hospitaleiros, prontos para o próximo viajante que enfrenta os percursos que emaranham visualidades, fraudes e preconceitos.

Observando os admiradores dos protagonistas da pesquisa, constatamos que as realizações imagéticas e discursivas de si sobre si e seus coletivos funcionam também como quebra da normatividade sobre gênero e sexualidade. A imagem é notadamente elemento constitutivo do cuidado de si e, logicamente, tem sua relevância e sentido no jogo dos trânsitos identitários, 
como observamos, tendo o corpo como elemento de partida e chegada na localização desses sujeitos meio a complexidade social. O corpo é, para esses jovens, um importante território de embate no qual as imagens impostas e excludentes se chocam com as imagens que lhes fascinam e lhes incluem, se não no acolhimento da sociedade dominante, em oportunos territórios de afeto. Esses jovens de alegria insurgente e autores de estéticas negadas e rejeitadas se reconfiguram em imagem de aceitação e posicionamento meio aos grupos que lhes interessam. As visualidades pessoais, vestimenta, cortes e cores de cabelo, acessórios e demais meios de expressão e estética pessoal funcionam como subversão estratégica da estética normativa moral e heteroreferencial. Como se dos rejeitos, do lixo das palavras às imagens, configurassem a aceitação entre si meio a seus coletivos. Passo decisivo para enfrentamentos mais desafiadores fora de seus territórios identitários.

Sublinhamos que a afirmação pretendida pelos jovens a qual aludimos só triunfa por começar nos micros coletivos dos quais emergem para, aos poucos, contaminar outras esferas das tribos e, assim, efetivar efeitos positivos para os seus autores. Esse processo não se finaliza nem é controlável, pois as imagens afirmadas a preços altos acabam, muitas vezes, sendo espoliadas pelo maquinário de consumo. O que interessa considerar é que as realizações emancipatórias, e consideramos assim as produções trabalhadas - discursos, imagens, vídeos e performances de Inês Brasil e do Bonde das Bonecas - sofrem, mais cedo ou mais tarde, certa oxidação regulatória (SANTOS, 2004 p. 17 - 55). Contudo, batalhas são vencidas e territórios, se não conquistados definitivamente, ao menos são desfrutados e atravessados.

A experiência estética que envolve o modo de viver juvenil - com seu manejo das imagens, da autoimagem e seus modos de circulação e vivências coletivas na rede - surge a partir dos recursos mobilizados nas suas produções e, reiteramos, são elementos emblemáticos da rejeição, imagens e contraexemplos da ordem estética e moral hegemônicas (mestiçagem, negritude, obesidade, precariedade material, etc.). Em relação aos artistas do Bonde das Bonecas e Inês Brasil, suas produções recorrem a recursos facilmente encontráveis no universo da Arte, contudo, de efeito político e cultural raramente encontrados com o mesmo sentido no universo da arte outorgada. Entendemos, ainda recorrendo a algumas concepções de Boaventura de Souza Santos (2004), como a ideia de uma racionalidade estético-expressiva é útil para melhor explicitar a valorização dos elementos centrais à nossa pesquisa. A ideia de racionalidade, de Estética e expressividade ou expressão não carregam delimitações que nos impeçam de aproximá-las e identificá-las nas produções e nos protagonistas de nossa aventura investigativa. 
Toda concepção poética, como as performances de Inês e do Bonde, envolve planos de racionalidade. Não necessariamente na perspectiva ainda dominante que polariza criação poética e ações ou atividades funcionais e práticas. A racionalidade que produz esteticamente mostra-se essencial nas agregações sociais. É em torno do espetáculo, seja religioso, artístico ou de qualquer procedência cultural, onde a comunidade reafirma sua agregação, se reconhece como manada e reitera seus laços afetivos.

\section{JUVENTUDES}

A juventude é vista como uma passagem entre as funções sociais da infância e as funções sociais do que é ser adulto. Ela nunca foi pensada exclusivamente sobre seu aspecto biológico ou também como termo jurídico (LEVI; SCHMITT, 1996 p. 7). A juventude sempre foi tomada por outros símbolos e valores de determinadas culturas e contextos históricos. É preciso salientar que os indivíduos não estão incluídos somente em grupos etários, eles transitam por momentos distintos. Nesse atravessamento sem tempo definido para início e término, esses sujeitos constituem dentro de sua sociedade a condição de jovem, caracterizando assim a juventude, "determinando tanto as atitudes sociais, a atitude dos outros no seu confronto, quanto à visão que os jovens têm de si mesmo" (LEVI; SCHMITT, 1996 p. 9).

Sendo a juventude o momento da vida de cada individuo que precede a idade adulta, ela é de grande importância para formação do cidadão. Por essa dentre outras razões, há permanente embate sobre como esse momento deve ser desfrutado, conduzido ou simplesmente superado. No decorrer dos séculos, muito tem se modificado na concepção das sociedades do que é "melhor” para seus jovens. Entretanto, essa concepção sempre é determinada por indivíduos que não estão mais presentes na juventude. Os adultos definem e exigem que as novas gerações assumam os papeis sociais já hegemonicamente estabelecidos e esses papeis geralmente variam entre modos diversos de exaltação da juventude como o futuro da nação e do mercado que precisa ser cuidado e glorificado. Quando o jovem nega os ideais ou programa a eles impostos, é visto como um desviante que demanda controle e repressão. 


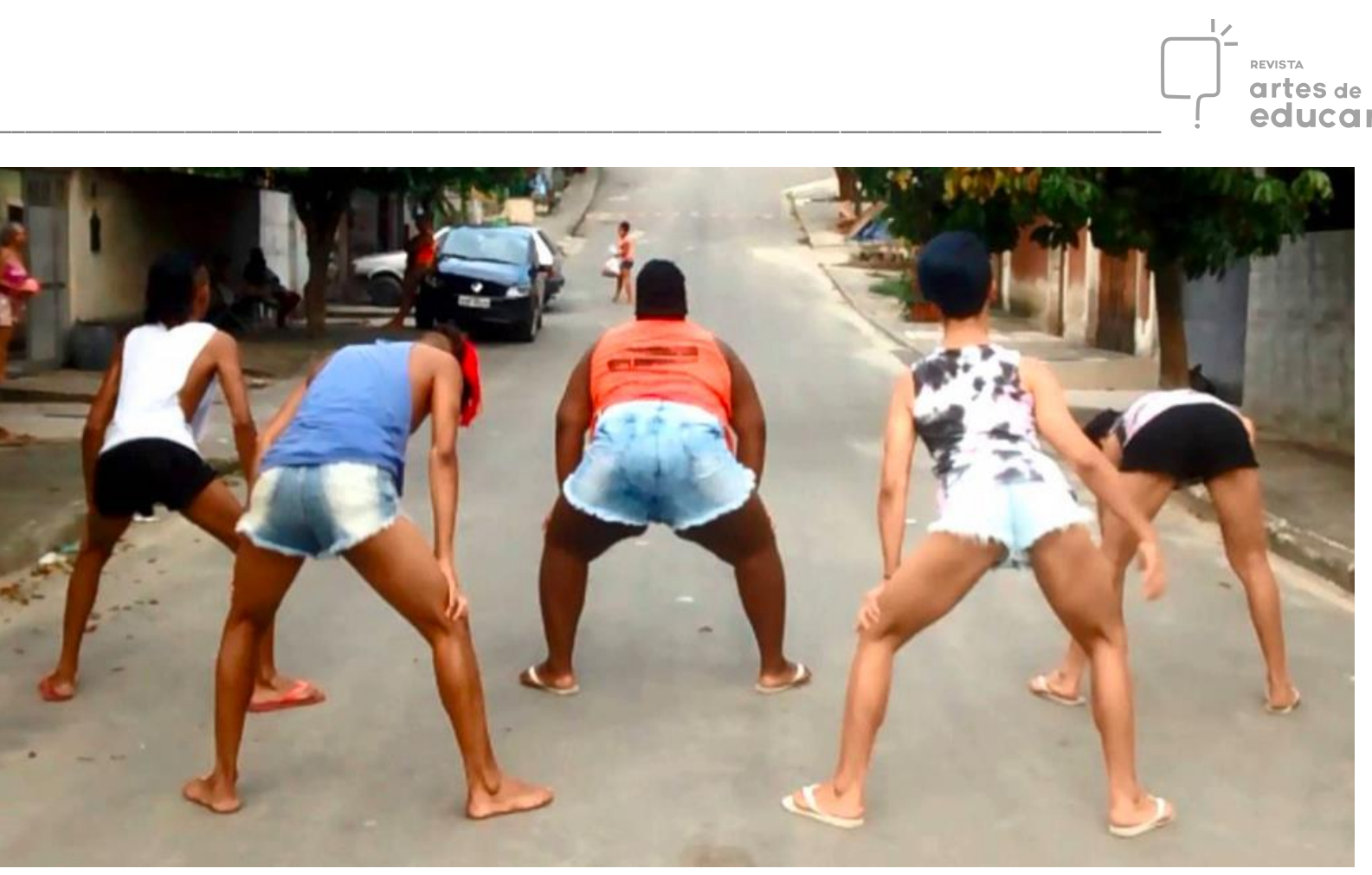

Fonte: Página oficial do Bonde das Bonecas no YouTube, (2016).

Durante muito tempo a juventude era abordada apenas em tratados religiosos e morais (CROUZET-PAVAN, 1996 p. 191). Livros serviam de manuais para as famílias imporem às proles regras de comportamento e deveres. Os termos mais encontrados nesses tratados eram "restringir", "moderar", "governar" e "regular" - uma evidente estratégia de cerceamento da liberdade e neutralização do desejo da juventude, privando-a, assim, de experimentar de novas possibilidades de existência. Ao longo do processo de forte regulação, as juventudes deveriam aprender desde cedo os seus papeis sociais, ou seja, o que delas se espera, o que lhes é permitido, o que devem evitar e o que devem cumprir.

Quando o bebê ainda esta no ventre materno, já se inicia a busca para descobrir o seu sexo, para já se definir a partir daí não só qual será o nome e a cor do quarto da criança, mas também as expectativas de seu futuro na sociedade, naturalizadamente, decorrente do gênero que lhe será imposto. Após o nascimento, a criança, quando possível, terá um quarto de cor rosa ou azul e demais objetos, roupas, brinquedos e imagens educativas a depender da conformação de sua genitália. As pessoas designadas meninas receberão bonecas e ao longo do tempo instruções específicas para incorporarem o gênero decidido. Com os meninos, se aplicará o mesmo procedimento de formação, contudo, direcionado a outra configuração da subjetividade, do comportamento, etc. Assim, eles ganharão carrinhos, armas e incentivos ligados ao estereótipo masculino. Modos e dispositivos vão ensinando a sentar, sorrir, olhar, em suma, estabelecem o roteiro a ser obedecido e a maneira adequada de realiza-lo. 
Esta imposição funciona como uma segunda pele aplicada sobre todo o corpo do individuo. As crianças são treinadas diante desses parâmetros em todas as instâncias da vida, na família, na vizinhança, na escola, fazendo com que essa segunda pele passe a funcionar como se fosse natural, como se as crianças tivessem efetivamente nascido com elas. A indiferença à autocriação, ou seja aos elementos e aspectos que as formam e espontaneamente e as levam aos planos de preferências eróticas, produz efeitos devastadores para os que não se adequam à rigidez do programa binário de gênero. $\mathrm{E}$ isso se pode observar desde a mais tenra idade.

Todo esse aprendizado passado à criança sobre o que é considerado pertinente ao feminino e ao masculino é acirrado ainda mais na adolescência. As máscaras sociais surgem e aderem aos corpos como tatuagens. A sociabilidade infantil permite ainda certa convivência de meninas e meninos em diferentes atividades coletivas. Já na juventude, o fato de haver o aprendizado da aproximação afetivo/sexual (olhar, paquera, "ficar", namorar), torna os domínios e fronteiras masculinas e femininas mais nítidas, com limites bem definidos e vigilância acirrada. Logo os procedimentos impostos tornam-se cobranças rigorosas e muitas vezes violentas. Os jovens passam a ser cobrados sobre suas atitudes, seus gostos e o cumprimento de deveres quase nunca negociados com alguma simetria entre pais, adultos e as novas gerações em jogo.

Desde muito tempo e em várias sociedades, o processo de regulação da juventude ocorre firme e, dele decorre a desobediência e resistência das novas gerações. Assim, paralela a conformação se dá a insurgência dos que não concordam, ou sequer poderiam escolher a concordância, com as imposições sociais que lhe cercam, conduzem e oprimem, afinal, o que forma as subjetividades não se restringe às determinações disciplinadoras. Experiências diversas concorrem com as orientações familiares, com as normas e leis, na formação dos sujeitos. Atualmente, é claramente perceptível a resistência ou recusa à aceitação de certos padrões de comportamento estabelecidos e cobrados à juventude. Tal fricção ou colisão se dá em diversos aspectos; sexual, de gênero, social e racial. E diante dos desafios à auto criação e afirmação das subjetividades, muitos jovens são levados a descobrir ou criar maneiras de burlar as regras e reivindicar o direito à existência plena na diversidade e liberdade para assumir o que desejam, independentemente do que o mundo adulto infira como risco, desperdício ou improdutivo. 


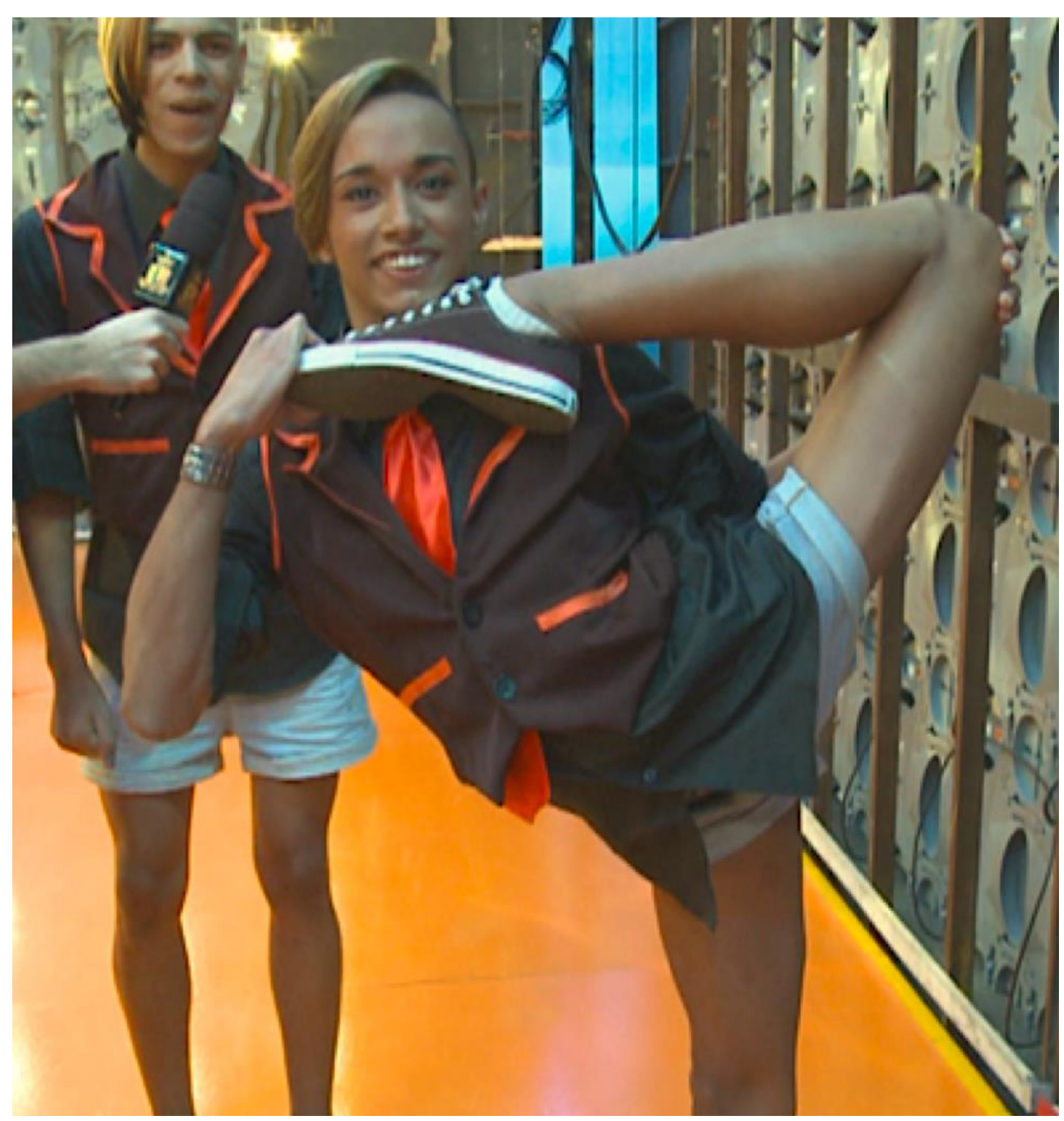

Fonte: Reprodução/Rede Record, (2013).

$\mathrm{Na}$ perspectiva das considerações elencadas, é preciso atender a necessidade de redefinir se não o próprio corpo, a sua compreensão. Ou seja, pensá-lo para além do esquema cristão (ONFRAY, 2005, p. 221), que o condena ao exílio e imobilidade na dualidade, mas o corpo como matéria aberta à sua auto realização na plenitude de qualquer poética que o faça feliz e portanto, eivado de dignidade e existência livre. Logicamente, então, não mero portador de um destino sobre o qual não opinou ou minimamente seja contemplado.

O corpo contemporâneo, nos mostra as juventudes, é efetivamente plano aberto à criação e ao fluxo magnético de energias e forças, é uma substância única, certamente, mas diversamente modificada, atravessada pelas experiências coletivas e percursos estéticos que combinados 
garante a cada um singularidade e importância. $\mathrm{O}$ corpo irredutível ao gênero ou à convenções sociais é indissociável da sua permanente autopoiese e surpreende em suas condições ainda inexplicáveis.

\section{O BONDE}

O grupo Bonde das Bonecas, constituído apenas por meninos, gays e afeminados, se formou a partir da decisão de encenar passos de funk antes coreografados por meninas, assim como regravar canções e criar suas próprias canções com temática positiva em relação às suas escolhas e afinidades estético visuais. A sua arte fulgura a beleza da sua diferença e assim, de maneira espontânea e franca resistem e exemplificam modos de resistência à cobrança normalizadora do comportamento da juventude. Evidenciam mudança significativa nas relações entre a juventude, a marginalização social e a comunidade. A cada novo vídeo postado ou apresentação em programas de televisão, bailes, etc., o Bonde performa à sua maneira um novo jeito de enaltecer as diferenças que estigmatizam jovens gays, negros, oriundos da periferia. Desse conjunto de estereótipos da rejeição, o Bonde edita suas visualidades na contracorrente do padrão estético dominante e assim faz emergir um contra exemplo da exclusão. E, dessa forma, ganham cada vez mais milhares de curtidas, comentários e compartilhamentos em redes sociais, alcançando maior fama e sucesso. O que nos leva a repensar afirmações redutórias sobre a força do conservadorismo e seu poder de exclusão. Contudo, nossas reflexões são permanentemente acompanhadas pela consciência de que a juventude representada pelo grupo ainda está entre as principais vítimas da violência e rejeição. Destacamos aqui a potencia das juventudes em manobrar o alvo da agressão e torna-lo objeto de admiração e exemplo positivo.

Ei, psiu, veado! / O Bonde das Bonecas vai lançando seu recado, / essa daqui é nova é a melo do veado. / Joga as mãos pra baixo, / rebolando vai de lado, / o refrão é muito fácil. / Vai assim ó / Vai veado! Vai Veado! Vai Veado! / Veado, veado, veado, veado, veado. / Vai veado! Vai Veado! Vai Veado! / Veado, veado, veado, veado, veado. / Dançando tu vai veado, / rebolando ate em baixo, / o quadradão é um esculacho. / Ih arrasou em. / Dançando tu vai de quadro, / de cabeça pra baixo no espaguete do veado. / Vai veado! Vai Veado! Vai Veado! / Veado, veado, veado, veado, veado. / Ih arrasou em! / Vai veado! Vai Veado! Vai Veado! / Veado, veado, veado, veado, veado. / Ih arrasou em! (Bonde das Bonecas, 2016) 
Importante observar que o prestígio do Bonde das Bonecas não se restringe ao ambiente e coletivos LGBT, mas, avança em outros ambientes, entre pessoas que têm acesso aos atuais veículos de informação. O que amplia a dimensão do seu valor como meio de diluição do preconceito contra comportamentos e escolhas estéticas que fogem às máscaras sociais autorizadas.

O pessoal do Bonde, assim como muitos outros jovens, sobretudo meio ao Funk, reivindica e enaltece a libertação dos padrões sociais que não lhes são favoráveis ou sequer se adequam às suas condições sociais e culturais. Os jovens favelados surpreenderam em suas primeiras performances realizadas em espaços públicos de sua comunidade, pois mostraram que a aparente audácia na realização de seu trabalho não provocaria necessariamente reação desfavorável ou agressiva. Ao olhar desarmado, as imagens dos primeiros vídeos mostrará entre muitos aspectos preciosos, fundamentalmente, meninos brincando numa das ruas de seu bairro. Claro que todo material videográfico é editável e mostrará centralmente o que interessa aos seus realizadores. Contudo, fica evidente a coragem, a alegria e a transviação exemplar desses meninos. Argumento forte sobre a capacidade da juventude da qual tratamos, de cada vez mais encontrar maneiras de fazer emergir belezas de onde antes apenas se apontaria o erro, o interditado, o grotesco e ou inapropriado.

Um dos aspectos a respeito do grupo que pensamos importante ainda destacar é que a sua performance artística, assim como de outros grupos juvenis em situação semelhante, funciona como um jogo, como uma brincadeira que sempre será uma relação mimética com outras situações anteriores. No caso da coreografia, trata-se de uma cópia/criação de tantas versões circulantes nas redes. A fé no jogo é a condição prévia para que nele a assimilação das imagens imaginárias se realize (WULF, 2013, p. 144) e assim a brincadeira, aconteça, a dança seja encenada. A brincadeira, aqui, cria uma irrealidade real, como toda arte o faz, e, com ela, a possibilidade de ir além dos limites duros da vida cotidiana. A performance artística ou lúdica, individual ou coletiva permite viver novas intensidades, ampliar modos de escape das vicissitudes, resistência à dureza da vida e, portanto, se estender para além de si, dos confinamentos sociais e mesmo tornar-se outro, sempre a favor de seus coletivos.

\section{EMBATES NO FUNK}

Sendo o Bonde das Bonecas um grupo de funk carioca, foi importante interesse desta pesquisa entender como se deu o embate meio a esse universo musical, muitas vezes considerado 
machista e homofóbico e machista, e os jovens LGBT. O funk no Rio de Janeiro é oriundo das favelas, e teve seu início nos anos de 1970, quando começaram a surgir bailes da pesada - black, soul, shaft ou o próprio funk. Segundo DJ Marlboro (1996 p. 32), o funk é “como a maioria de nossas influências musicais de ritmo quente, forte, a origem do funk é da música africana e surgiu, inicialmente, com os negros americanos".

Entre as décadas de 80 e 90, tínhamos então uma predominância de produções masculinas e com um viés de guerra: montagens ${ }^{\mathrm{iv}}$ de brigas de galeras, "proibidões" paz nos bailes e orgulho de morar nas favelas. Apenas na virada dos anos 2000, quase 30 anos depois, começou a emergir um protagonismo feminino dentro desse universo.

Como parte da tematização e performances erótico-sexual dessa nova temática podemos observar a elaboração de um discurso masculino que procura classificar o corpo das mulheres (popozuda, filé, etc.) e seus comportamentos sexuais (preparadas, tchutchucas, cachorras, danadas). (MATTOS, 2006, p. 42)

Com o repertório da "guerra dos sexos" (Ibid.) muitos MCs e DJs colocam em suas músicas um viés machista, transformando a mulher em um objeto sexual ou "interesseiras". Os clipes e apresentações nos Bailes Funk reforçam ainda mais essas ideias, colocando mulheres como figuras decorativas com roupas mínimas e danças lascivas, se contrapondo à figura do homem que, além de ser supervalorizada, é colocada como o "ativo" versus a fêmea "passiva" até na performance artística.

Como é sabido, em muitas sociedades do mundo, como no Brasil, ainda vigora a classificação e hierarquização das pessoas a partir de sua sexualidade e de seu gênero. Um desses processos, bastante disseminado entre as sociedades, é a ideia do homem heterossexual como o "ativo" em uma relação sexual, em dicotomia com a mulher ou o homem homossexual - "bichas" ou "viados" - tidos como socialmente femininos e "passivos" e que adotam o papel exclusivo de recepção ao serem penetrados. Reforçado, nessa estereotipia dois papéis apenas, o do herói vencedor com poder legitimado, e o subjugado, o vencido, aquele cuja função é servir o vencedor a custa do seu próprio aviltamento e humilhação. Tal imagem ainda convence a muitos e serve de argumento, cada vez mais roto, mas, ainda útil ao jogo covarde entre machos e os outros, a despeito de não passar de um jogo retórico e imagético de mitos de sustentação do 


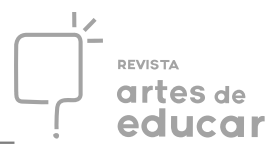

heteronormativismo machista e da banalização da violência e inferiorização do universo feminino e dos não tributários ao cisgênero ou à heterossexualidade.

Enfrentando essa dicotomia, surge uma cantora que se propõe a discutir a objetificação e passividade da mulher. Tati Quebra-Barraco (2004) chega com "Sou cachorra, sou gatinha, não adianta se esquivar, vou soltar a minha fera, eu boto o bicho pra pegar", e quebra a imagem de "passiva" da mulher dentro do funk carioca ao se colocar como personagem principal em suas músicas, como mulher "ativa" que "está podendo pagar hotel pros homens, isso é que é mais importante”. Surpreende com o óbvio, pois sua poética peculiarmente feminista emerge de um universo social no qual as mulheres são majoritariamente chefes de família ${ }^{\mathrm{vi}} \mathrm{e}$ mantenedoras de seus lares, responsáveis, evidentemente, por grande parte da sobrevivência de suas comunidades.

Tati consegue, por meio de suas canções e performances, assim como em seus depoimentos para a mídia, abrir espaço para que outras cantoras e grupos compostos apenas por mulheres surgissem dentro do universo do Funk, antes dominado por homens. A Gaiola das Popozudas é um exemplo da mudança desse cenário. O grupo, criado nos anos 2000, foi formado apenas por mulheres e teve, até 2012, Valesca Popozuda como vocalista. Em seu repertório, encontramos músicas que valorizavam a imagem da mulher dentro do funk e exaltam a sua liberdade sexual.

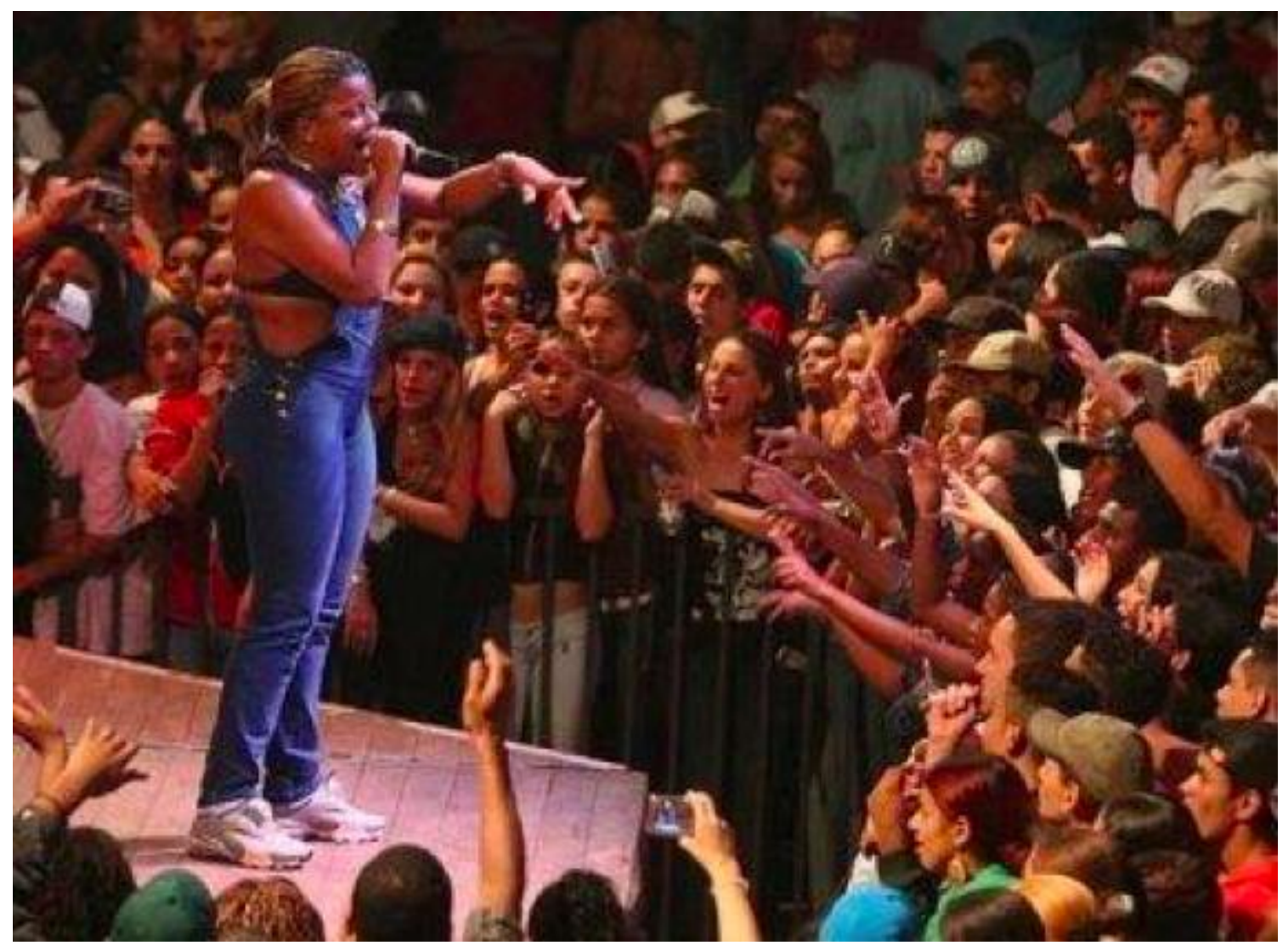


Fonte: Site Pinterest. Foto: Fernando Dantas, (2007).

E aí, seu otário / Só porque não conseguiu foder comigo / Agora tu quer ficar me difamando, né? / Então se liga no papo / No papo que eu mando. / Eu vou te dar um papo / Vê se para de gracinha. / Eu dou pra quem quiser / Que a porra da boceta é minha! / É minha! É minha! / A porra da boceta é minha! / É minha! É minha! / A porra da / Se liga no papo, / No papo que eu mando: / Só porque não dei pra tu / Você quer ficar me exclamando. / Agora, meu amigo, / Vai tocar uma punhetinha, / Porque eu dou pra quem quiser, / Que a porra da boceta é minha. / É minha! É minha! / A porra da... / É minha! É minha! / A porra da boceta é minha! / É minha! É minha! / A porra da boceta é minha! / É minha! É minha! / A porra da... (Gaiola das Popozudas, 2006)

Na cama faço de tudo / Sou eu que te dou prazer / Sou profissional do sexo / E vou te mostrar por que / Minha buceta é o poder / Minha buceta é o poder / Mulher burra fica pobre / Mass eu vou te dizer / Se for inteligente pode até enriquecer / Minha buceta é o poder / Minha buceta é o poder (Id., 2010)

Nesse contexto, as figuras LGBT - lésbicas, gays, bissexuais, pessoas trans e travestis - sempre foram vistas também como "passivas", com o significado, como anteriormente mencionado, de inferioridade. Afinal, no senso comum, ainda entendimento de grande parcela da sociedade, o homem gay é aquele que abre mão de sua masculinidade para viver como uma mulher, tendo a condição feminina como algo menor e independente da identidade de gênero, pois, ainda é desastrosamente entendido identidade de gênero e orientação sexual como sendo a mesma coisa. No funk, em muitas canções, não se dá de forma diferente e a imagem do gay é apresentada como algo engraçado, grotesco e ofensivo. Chamar alguém de gay dentro do universo do funk carioca foi por muito tempo, uma ofensa, e até hoje, na maioria dos espaços, ainda é assim. Afinal, o isolamento das comunidades é sobretudo no aspecto das benesses sociais e não na impermeabilidade de características comuns às classes que lhe são antagonistas. Muito embora, como vimos com o Bode das Bonecas, há espaço para acontecimentos emancipatórios e de resistência. 
Lacraia foi uma travesti e dançarina que compôs a dupla com o MC Serginho. Mesmo eles formando o grupo Serginho e Lacraia, ela era apenas sua dançarina e ele, o cantor, integrante principal do grupo. Exemplo disso é a música "Vai Lacraia", em que ela, apesar de ser a personagem principal retratada na música, era meramente a dançarina, e quem tinha a voz era Serginho.

O Bonde das Bonecas é, então, um dos primeiros grupos de funk carioca formado apenas por LGBTs que se tornou conhecido. Se empoderarvii através de performances, vídeos e imagens faz parte desse embate e desses espaços de "minorias" sexuais e de gênero dentro do funk. Suas visualidades corporais no meio virtual estão, de uma forma ou de outra, abrindo possibilidades para novos grupos se inserirem nesse universo que até então não tinham abertura para se colocar e reverter a imagem de meramente "passivos". 


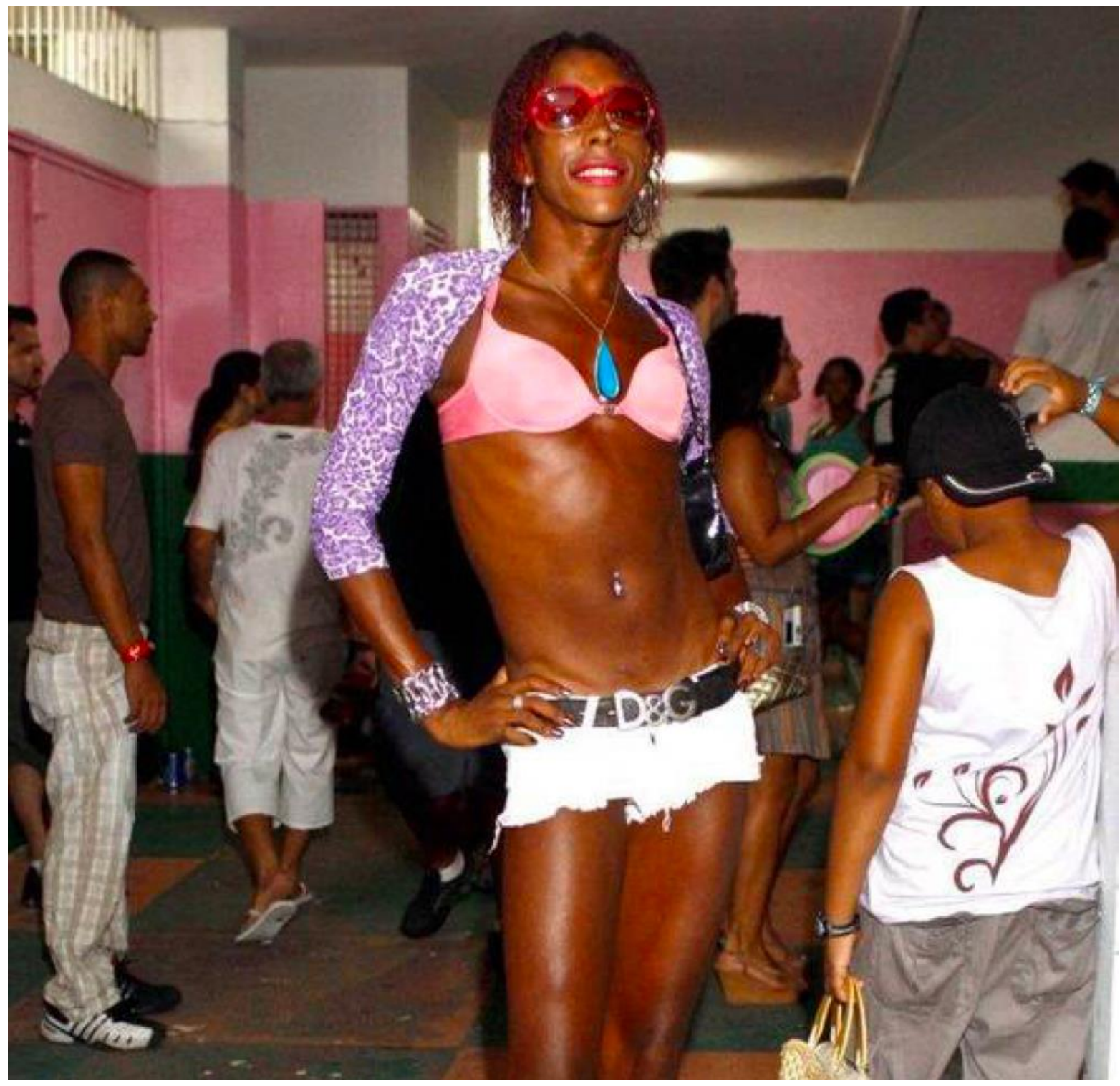

Fonte: Site do jornal Extra. Foto: Roberto Filho/Divulgação, (2009).

\section{AS REDES}

Distinto de qualquer outro momento da história da humanidade, hoje é possível conversar e enviar textos, imagens, músicas, vídeos, de forma instantânea para uma ou várias pessoas de qualquer parte do mundo mediante ao apoio de um aparelho de celular. Os tempos atuais presenciam uma gigantesca e intensa "viralização" de visualidades. O trânsito de imagens via redes de comunicação virtual alcançam inimaginável volume, trânsito incontrolável que contém todo tipo de imagem. Mirzoeff (2015 p. 62) destaca que só de selfies, houve, em 2013 na Grã- 
Bretanha, a divulgação de bilhões de imagens! Em meio à atual configuração da cultura visual, imagens que, há algum tempo seriam consideradas incomuns circulam junto a novas maneiras de uso e criação visual. Como exemplificam as imagens dos protagonistas deste estudo, emergem e circulam, muitas vezes carregadas de derrisão e deboche, se oferecendo a apropriações diversas e, assim, contribuído para a emergência e visibilidade de uma quantidade de jovens que se veem representados e/ou identificados nessas imagens.

Julgamos importante, em benefício do melhor entendimento da dimensão ocupada pela imagem no plano virtual, retomar algumas considerações do autor ainda em relação ao selfie. Criação e compartilhamento da imagem que se escolhe para si. Mutável, editável, substituível, enfim, livre na inventividade das redes. No capítulo "Selfies e a maioria planetária" (Ibid. p. 63) do seu livro "How to see the world", o autor observa que, na atualidade de grandes e intensas transformações, as categorias de identidade estão sendo refeitas e reformuladas. Citando o estudioso da teoria queer Jack Halberstam em sua afirmação de que "os tijolos de construção da identidade humana imaginada e cimentada no último século - o que chamamos de gênero, sexo, raça e classe mudaram tão radicalmente que uma nova vida pode ser vislumbrada no futuro", Mirzoeff afirma que o lugar onde podemos perceber estes vislumbres é a selfie. Isto porque, quando as pessoas comuns se produzem e posam da melhor forma que podem para a selfie, elas alcançam momentaneamente o papel de artista-como-herói (Id.). Cada selfie seria uma performance, uma criação artística da sua própria imagem, ou seja, da imagem que desejaria ser vista pelos outros. A selfie, teria então, adotado a estética tecnologizada do pós-modernismo e adaptada para audiência ilimitada da Internet.

O fato inquestionável é que online ou nas novas interações no mundo real com tecnologia, nós experimentamos o avanço e desdobramento atualizadores da Cultura Visual. 


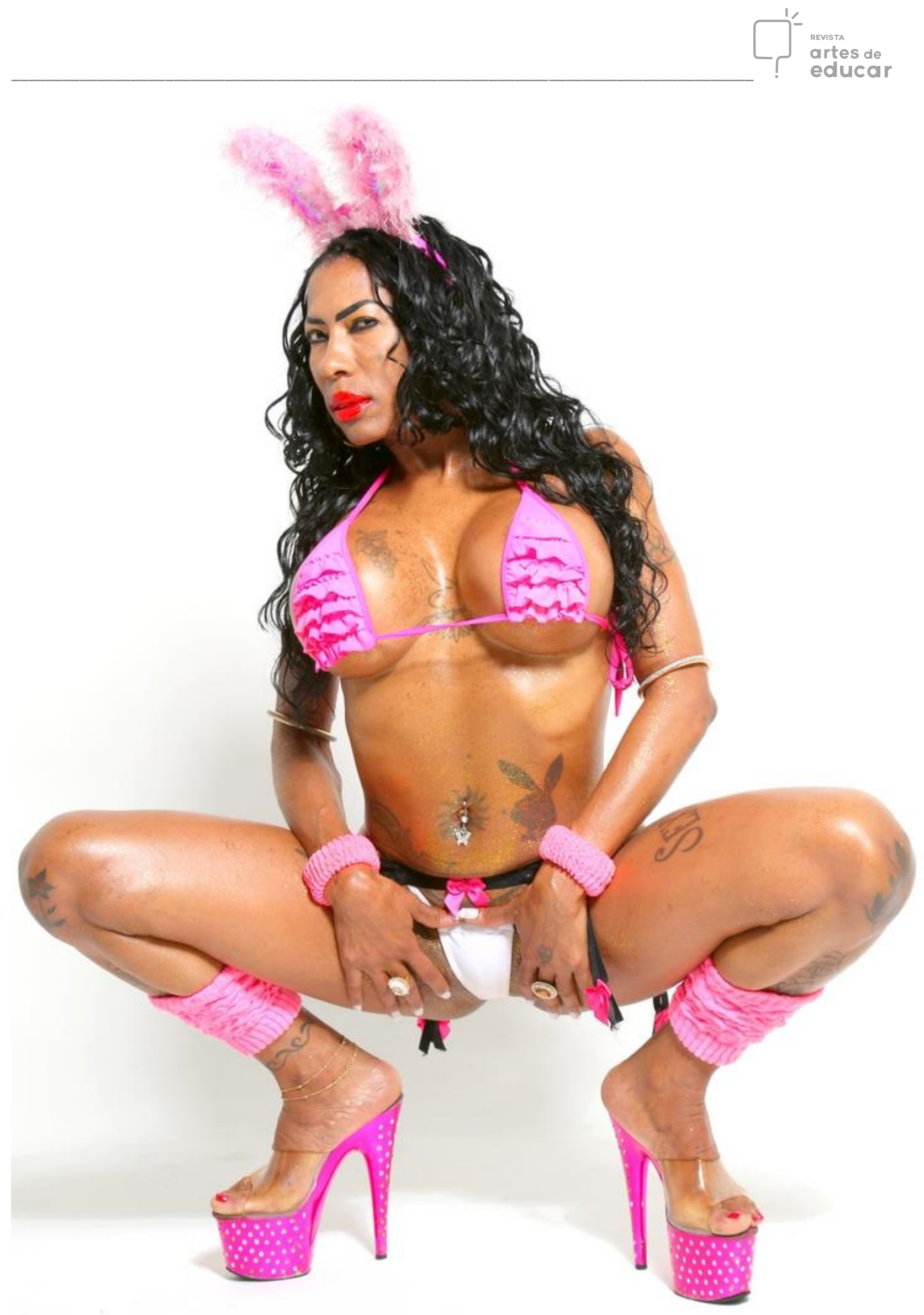

Fonte: Site da rádio Joven Pan, (2017). 


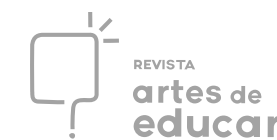

Efetivamente, nossos corpos habitam e circulam na rede e no mundo ao mesmo tempo. A despeito dos julgamentos desqualificadores da cultura da performance digital como desastre estético e a obsessão pela autoimagem, o mais importante a ser considerado é a sua novidade e o poder da imagem de criação livre e circulação ilimitada. Portanto, o que já poderíamos afirmar com alguma certeza sobre a interação, uso e exploração da rede global pelos jovens é que ela sempre se modificará de forma frequente e imprevisível. Elas apresentam formas e caminhos que fatalmente poderão não fazer sentido para as gerações antigas e desafiá-las a repensar suas convicções a respeito dos assuntos que os jovens fazem e farão circular na grande rede.

As muitas imagens produzidas pelos jovens e lançadas na rede são fontes indispensáveis para a compreensão da atualidade e, sobretudo, das realidades das juventudes. Vídeos capturados na rede e editados domesticamente, memes, gifs e selfie são novas formas de conversação visual digital. As selfies, por exemplo, são a primeira forma da nova maioria global se lançar fora do reduzido espaço do indivíduo. E isso é muito significativo. Conforme os estudos apresentados por Mirzoeff (2015 p. 63) na obra citada,

...o fenômeno da "selfie" começou após o lançamento de câmeras frontais de melhor qualidade com o iPhone 4 em 2010, com outros modelos de telefone seguindo rapidamente. Selfies poderiam agora ser tiradas fora de casa ou usando flash sem resultar em um borrão de luz dominando a foto, como as fotos tiradas em espelhos, que eram essenciais na rede social Orkut nos seus tempos áureos de 2004 a 2010. Uma "selfie" é agora entendida como uma foto de si mesmo (ou incluindo a si mesmo) que se tira o próprio segurando a câmera no comprimento do braço. Um vocabulário visual padrão para a selfie padrão tem emergido. Elas saem melhor se tiradas de cima com o sujeito olhando para cima, para a câmera. A foto geralmente concentra no rosto, com o risco de fazer uma "duck face”, que seria “fazer beicinho”. Se você exagerar e sugar suas bochechas demais, voilá, a duck face. Essas poses estão refazendo o autorretrato global. Apesar do nome, a selfie é na verdade sobre grupos sociais... 
É evidente que a descoberta das possibilidades da rede e das tecnologias de produção e edição de fotos foi acompanhada pelo desenvolvimento da atenção e habilidades do trato com o visual. Se uma quantidade gigantesca de pessoas busca obedecer aos padrões estéticos dominantes na elaboração de suas imagens visando objetivos variados, outro grupo encontra na rede e no domínio de seus usos um campo de militância. Portanto, a tendência a compartilhar o que se apontaria como "selfies feias" ou selfies não-convencionais é também notável.

Enquanto a exposição das autoimagens, ou selfies aumentava vertiginosamente, certo pânico moral emergia na mídia (Agger, 2012). Conforme Mirzoeff (2015 p. 65) cita em seu livro, um comentário típico, vindo de um comentarista da $\mathrm{CNN}$, um canal a cabo de notícias norteamericano, Roy Peter Clark, dizia: "Talvez a conotação da selfie seja egoísta, absorta em si mesmo, narcisista, o centro do universo, um salão de espelhos em que cada reflexo é o de si próprio". Entretanto, outros captaram a novidade de outra forma não menos discutível, como é o exemplo citado da revista Esquire, também norte-americana, na qual a escritora Stephen Marche declarou que a selfie seria a "masturbação da autoimagem", afirmando, contudo, que isso seria um elogio, pois a realização da selfie é controlada e proporciona liberação. Entretanto, tais metáforas distorcem ainda a amplitude do uso e exploração das redes por meio das imagens. "Narciso passou sua vida olhando para si mesmo, mas ele não liberou uma cópia da sua imagem para que os outros pudessem olhar para ela" (Ibid.).

A imagem de si e de seus ídolos ou coletivos remetem inexoravelmente ao compartilhamento. E isso não poderia ser classificado como masturbação, ou seja, algo que acontece na privacidade do indivíduo. Seria, portanto, antes de mais nada, um convite para que os outros curtam, desaprovem, se sintam provocados, afetados, aproximados, aprendam e reajam. Ou seja, que considerem o que você fez e participem de uma conversação visual. Enfatizando a potência das redes e do panorama no qual nossos protagonistas resplandecem e ampliam sua fama. Algo grandioso acontece, como os números sugerem, na Inglaterra, 35 milhões de selfies foram postadas na internet em cada mês do ano de 2013. Na metade de 2014, o Google afirmou que 93 milhões de selfies eram postadas mundialmente a cada dia, mais de 30 bilhões em um ano (Ibid.). 


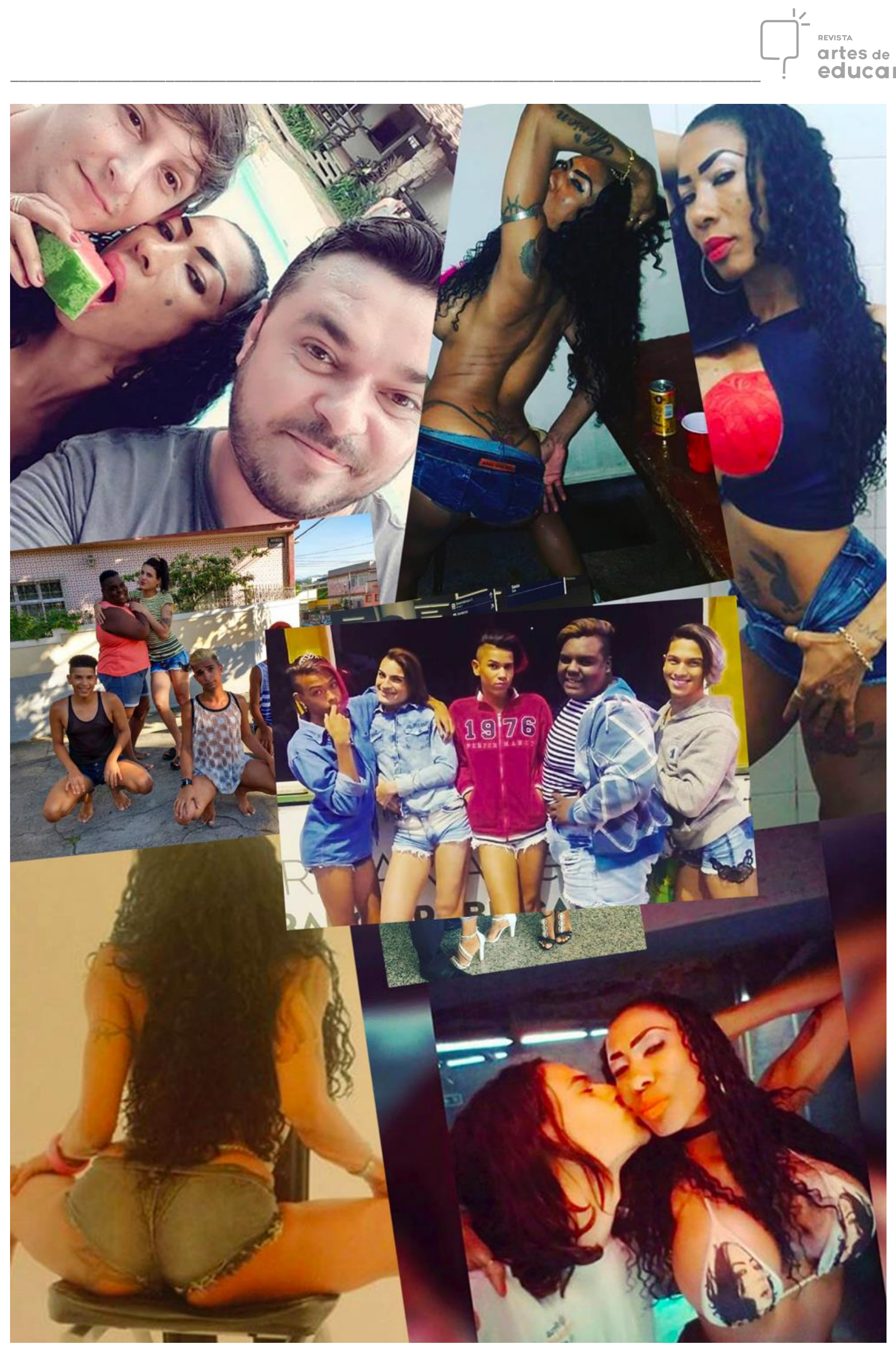

Fonte: Páginas oficiais do Bonde das Bonecas e da Inês Brasil no Facebook, (2017). 
Nesse movimentado universo, Inês Brasil e o Bonde das Bonecas se destacam de forma diversa aos grupos musicais e "Divas Pop" geralmente apoiados pelo maquinário e capital da indústria do entretenimento, conquistando por seus próprios meios e redes a relevância e o afeto de seus admiradores. No início de suas aparições, sem qualquer apoio comercial, atraíram a atenção e simpatia de milhares de jovens, não apenas pelas qualidades comuns às divas eleitas pelas mídias comerciais, mas, sobretudo, pela maneira de afirmar a liberdade que almejam e possibilitam.

A aparente e, sob alguns aspectos concreta, precariedade de condições materiais faz com que Inês e o Bonde recorressem a meios alcançáveis e nada sofisticados em termos tecnológicos e estéticos. E eles o fizeram com notável inventividade. A falta de investimento de capital permitiu a plena liberdade na construção de suas imagens visuais, liberdade na pronúncia e do sotaque de seus discursos e produções poéticas ou artísticas, imagens e falas livres da perícia estética mainstream, se deviam algo a alguém foi a eles próprios, no sentido de satisfazer plenamente seus desejos artísticos. Isto resultou em muitas formas de improvisação, cujas ousadias redundaram na elaboração de estéticas singulares que descortinam a parte mais brilhante e doce de suas existências, pois, as visualidades que realizaram e realizam são muito familiares, até mesmo íntimas, aos seus inúmeros interlocutores.

Nossa investigação reitera a ideia de que as elaborações estéticas, áudio e visuais ecoam mais forte do que discursos racionalizados nas subjetividades dos jovens que se identificam e acolhem os artistas, suas imagens, suas visualidades. Cada detalhe visual e discursivo, cada vídeo ou foto aporta uma infinidade de indícios e conexões do universo afetivo e existencial particular às multidões de admiradores dos artistas. Há uma contra estética, ou seja, uma estética que emerge do que os padrões dominantes refutam e condenam ao apagamento - a voz do favelado, a cor do favelado, o corpo da mulher sem recato, a deselegância da pobreza, a abominação da bicha afeminada, a aparência execrável da prostituta pobre, o desconcertante transgêneros, enfim, tudo o que fere e escapa ao controle e regime estético das classes dominantes.

Em nossa pesquisa, percebemos como os admiradores da Inês e do Bonde veem em suas manifestações artísticas verdadeiras possibilidades de fortalecimento de suas realidades e diferenças. E não se privam de utilizar e reutilizar essas manifestações dentro da rede através de memes, músicas, vídeos, etc. formando outros encadeamentos de resistência, de formação e afirmação de novas existências, na medida em que, recorrendo ao vocabulário viado, botam a cara no sol. Afinal o primeiro passo político é a recusa à invisibilidade e à passividade aquém de qualquer experiência erótica, social ou política. 


\section{REFERÊNCIAS}

AGGER, Ben. Oversharing: presentations of self in the internet age. Londres: Routledge, 2012.

Bonde das Bonecas. Vai veado. Rio de Janeiro: Master Power Record's, 2016.

BONDIA, Jorge Larrosa. Notas sobre a experiência e o saber de experiência. Revista Brasileira de Educação, n. 19, 2002.

BOURRIAUD, Nicolas. Estética relacional. Buenos Aires: Adriana Hidalgo, 2006.

BRASIL, Inês. Alô Alô Vc Sabe Quem Sou Eu - Eu Vou Te Contar Que Vc Não Me Conhece.... Disponível em: < https://www.youtube.com/watch?v=xlUSM3f0m1s >. Acesso em: 30 abr. 2017.

CONNELL, Robert W. Políticas da masculinidade. Educação \& Realidade, n.20, v.2, p.185206, 1995.

CROUZET-PAVAN, Elisabeth. Uma flor do mal: os jovens na Itália medieval. In: LEVI, Giovanni; SCHMITT, Jean-Claude (Org.). História dos jovens 1: da antiguidade a era moderna. São Paulo: Companhia das Letras, 1996.

FOUCAULT, Michel. História da sexualidade, I : a vontade de saber. Rio de Janeiro: Graal, 2003.

. História da sexualidade, 2: o uso dos prazeres. Rio de Janeiro: Graal, 2003.

História da sexualidade, 3: o cuidado de si. Rio de Janeiro: Graal, 2002.

. Os anormais. São Paulo, Martins Fontes, 2001.

FREIRE, Paulo. Pedagogia da autonomia. Rio de Janeiro: Paz \& Terra, 2013.

GAIOLA DAS POPOZUDAS. A porra da buceta é minha. 2006. Minha buceta é o poder. 2010.

HALL, Stuart. Da diáspora: identidades e mediações culturais. 2. reimpr. rev. Belo Horizonte: Editora UFMG, 2009. 
HERNÁNDEZ, Fernando. A cultura visual como um convite à deslocalização do olhar e ao reposicionamento do sujeito. In: MARTINS, Raimundo; TOURINHO, Irene (Org.). Educação da cultura visual: conceitos e contextos. Santa Maria: Editora UFSM, 2011.

Inês Brasil. Make love. Rio de Janeiro: Videobes, 2015.

LEVI, Giovanni; SCHMITT, Jean-Claude (Org.). História dos Jovens 1: da antiguidade a era moderna. São Paulo: Companhia das Letras, 1996.

LOURO, Guacira Lopes (Org). O corpo educado: pedagogias da sexualidade. Trad. Tomaz Tadeu da Silva. Belo Horizonte: Autêntica, 1999.

- Teoria queer: uma política pós-identitária para a educação. Revista de Estudos Feministas, Florianópolis, 2001. Disponível em: 〈http://www.scielo.br/pdf/ref/v9n2/8639.pdf〉. Acesso em: 30 abr. 2017.

Um corpo estranho: ensaios sobre a sexualidade e teoria queer. Belo Horizonte: Autêntica, 2008.

MAFFESOLI, Michel. O tempo das tribos: o declínio do individualismo nas sociedades de massa. Rio de Janeiro: Forense Universitária, 2000.

MARLBORO, Dj. Dj Marlboro (Por Ele Mesmo): o Funk no Brasil. Rio de Janeiro: MAUAD, 1996.

MARTINS, Raimundo; TOURINHO, Irene (Org.). Educação da Cultura Visual: conceitos e contextos. Santa Maria: Editora UFSM, 2011.

MATTOS, Carla dos Santos. No ritmo neurótico: cultura funk e performances 'proibidas' em contexto de violência no Rio de Janeiro. 2006. Dissertação (Mestrado em Ciências Sociais) Faculdade de Ciências Sociais, Universidade do Estado do Rio de Janeiro, Rio de Janeiro, rio de Janeiro, 2006.

MIRZOEFF, Nicholas. How to See the World: an introduction to images, from self-portraits to selfies, maps to movies, and more. Nova Iorque: Basic Books, 2015.

ONFRAY, Michel. La puissance d'exister. Paris: Le livre de poche, 2005. 
OLIVEIRA, Inês Barbosa de. Currículos praticados: regulação e emancipação no cotidiano escolar. 2003. Disponível em: < http://26reuniao.anped.org.br/trabalhos/ inesbarbosadeoliveira.pdf >. Acesso em: 30 abr. 2017.

SAFATLE, Vladimir. O circuito dos afetos: corpos políticos, desamparo e o fim do indivíduo. Belo Horizonte: Autêntica Editora, 2016.

SANTOS, Boaventura de Sousa (org.). Conhecimento prudente para uma vida decente: um discurso sobre as ciências revisitado. São Paulo: Cortez, 2004.

A Crítica da razão indolente: contra o desperdício da experiência. São Paulo: Cortez, 2000.

Tati Quebra-Barraco. Boladona. Rio de Janeiro: Link Records, 2004

. Sou Feia, Mas Tô Na Moda. Rio de Janeiro: Link Records, 2004.

TAYLOR, Roger L.. Arte inimiga do povo. São Paulo, SP: Conrad, 2006.

VICTORIO FILHO, Aldo e BERINO, Aristóteles de Paula. Meninas do Rio: o que cantam e contam nas paradas do proibidão. Disponível em: < http://www.fazendogenero.ufsc.br/7/artigos/B/Berino-Victorio_Filho_01.pdf >. Acesso em: 30 abr. 2017

WULF, Christoph. Homo Pictor: imaginação, ritual e aprendizado mimético no mundo globalizado. São Paulo: Hedra, 2013.

\footnotetext{
i Graduado e licenciado em Artes Visuais pelo Instituto de Artes da Universidade do Estado do Rio de Janeiro (Uerj), especialista em Gênero e Sexualidade pelo Instituto de Medicina Social da Uerj em parceria com o Centro Latino-Americano em Sexualidade e Direitos Humanos e Mestre em Artes e Cultura Contemporânea pelo Programa de Pós-graduação em Artes da Uerj.

ii Graduado em Gravura pela Escola de Belas Artes UFRJ e Licenciado em Educação Artística. Mestre e Doutor em Educação pela Universidade do Estado do Rio de Janeiro - UERJ. Professor associado, Coordenador do curso de Licenciatura em Artes Visuais Docente do Programa de pós-graduação em Artes - PPGARTES e do Programa de pós-graduação em Educação - PROPED ambos da UERJ.

iii Graduada e licenciada em História da Arte pelo Instituto de Artes da UERJ. Mestranda em Educação pela Universidade do Estado do Rio de Janeiro - UERJ. Professora de Artes Visuais no Município do Rio de Janeiro.

iv É um termo utilizado dentro do universo do funk para se referir a músicas que são junções de duas ou mais músicas.
} 
${ }^{\vee}$ Versões proibidas que tematizam as letras de facções do crime e as com conteúdo pornográfico. Este repertorio é comercializado de forma clandestina e em bailes de favelas por serem espaços e atividades de mercado ilegais/informais.

vi http://www.brasil.gov.br/cidadania-e-justica/2015/05/mulheres-comandam-40-dos-lares-brasileiros

vii Ideia das pessoas alcançarem o poder, a liberdade e a informação que lhes permitem tomar decisões e participar ativamente da sociedade de maneira geral. 